\title{
Notice on the Recent Ornithological Publication.
}

"The Practical Value of Birds." By Junius Henderson, Professor of Natural History and Curator of Museum, University of Colorado. Pp.xii+342. Published by the Macmillan Company, New York, May, 1927.

We have been presented the above book from tho publishers and requested to insert some notice on it on our bulletin "TORI."

On reading it carefully, we have found that it is very rare and valuable as the book of Econonic Ornithology. Hitherto, the books of this kind, are mostly of sectional investigation and not so synthetic as this book, which is containing the nearly all kinds of birds in North America, and showing the classification by A. O. U. Check List inserted therein, as to their species and subspecies with the number of stomachs examined and average number of food. It also contains many useful footnotes on the literatures of food, showing the result of examinations after the contents taken from stomachs of birds, and the general readers wishing to obtain moro detailed knowledgos on the subject can gather them by referring to those books, bulletins, etc. mentioned in the above footnotes.

The contents of the book consist of two parts. The first part contains the genoral discussion occupying over ono hundred pages, divided into 17 chapters, which principal subjects are "Esthetic and Practical Value of Birds," "Crops and Forests saved by Birds," "Birds as Enemies of injurious Insects, Mammals and Plants," "Birds as Scavenger's and Disease 
Carries," "Destruction of Birds," "Remedies," etc., etc. The second part contains the systematic discussion on the orders and families of every forms of birds, begining from "Order Pygopodes" to "Order Passeres," which occupy orer 170 pages.

The book also inserts the "Bibliography" of 27 pages, which comprises nearly all the important American papers (527 in number) of the Economic Ornithology, being arranged by an alphabetical order. In addition to the above, the index counting 23 pages is bringing up the rear.

After all this book is very useful to study the food-habits of North Ameriean birds, also one of most important reference to explain the relation between the birds and the material welfare of human race, and has a speciality be casily understood even by very busy people. As we have never seen so a complete book as this publication in the circle of Economic Ornithology, we wish that these kind of works would in a future be published successively in every country of the world.

In conclusion, we express our deep appreciation for the kind efforts of the author and publishers of the work.

Nagamichi Kuroda, Editor of "Tori." 